\title{
International Journal of Research Publication and Reviews
}

Journal homepage: www.ijrpr.com ISSN 2582-7421

\section{Flow of Finance to the MSME Sector in India-Micro, Small and Medium Enterprises}

\author{
Dr. Nalla Bala Kalyan ${ }^{1}$, Mrs. Toopalli Sirisha ${ }^{2}$ \\ ${ }^{1}$ Associate Professor,Sri Venkateswara College of Engineering,Karakambadi Road, Tirupathi-517507 \\ Chittoor District, Andhra Pradesh \\ ${ }^{2}$ Assistant Professor,Department of Management Studies,Sri Venkateswara College of Engineering,Karakambadi Road, Tirupathi-517507 \\ Chittoor District, Andhra Pradesh \\ DOI: https://doi.org/10.55248/gengpi.2022.3.2.14
}

\section{ABSTRACT:}

MSMEs are expanding their sphere of influence across the economy, generating a diversified range of products and services to fulfill the needs of both domestic and global markets. MSMEs (micro, small, and medium-sized firms) have gotten a lot of attention in India recently, because to their strategic relevance to the economy and the country. MSMEs play a critical role in the creation of jobs. A total of 111.4 million individuals are employed by the country's 48.8 million MSMEs. MSMEs in the manufacturing sector alone manufacture over 6,000 goods and account for 7.7\% of the country's GDP. Similarly, MSMEs provide 27.4 percent of the country's GDP in the services sector

Keywords: Finance, MSME (Micro, Small and Medium Enterprises), India, Schemes

\section{Introduction}

Micro, small, and medium enterprises (MSMEs) are accurately referred to as the Indian economy's backbone. Manufacturing, servicing, retailing, financing, building, and infrastructure are just a few of the activities covered by MSMEs. Over the previous 50 years, nations that have supported their brave entrepreneurs have thrived and prospered, while those that have erected hurdles to the growth of their small business businesses have ranked low on the performance graph. Even in countries where supporting entrepreneurial activity was previously discouraged or outlawed in favor of relying on the government to drive economic growth, there is now a rising recognition of the need of doing so.

Micro, Small, and Medium-Sized Enterprises (MSMEs) require more labor and less capital. This sector contributes to the elimination of regional imbalances and economic backwardness in both developed and developing economies. MSMEs promote equitable, sustainable, inclusive, and employment-friendly economic growth in India. Apart from that, by expanding the representation on the stage of transition from traditional to modern technology. This industry promotes the use of local skills as well as advanced technologies.

\subsection{Definition}

Micro, small, and medium-sized businesses are considered the backbone of any economy. Every economy is paying close attention to guarantee that MSMEs continue to grow. These industries not only serve to tackle the problem of unemployment, but they also help to eliminate inequities and produce foreign exchange through export. MSMEs have long been seen as a major engine of economic growth and a means of fostering the country's equitable and long-term development. The main benefit of this industry is that it provides employment at a low cost of capital. In comparison to largescale sectors, MSMEs have a higher labor intensity. The new categorization will take effect on July 1, 2020. The MSMED Act of 2006 had a previous criterion for classifying MSMEs that was based on investment in plant and machinery/equipment. Manufacturing and service units were treated differently. In terms of financial constraints, it was likewise quite low. The economy has seen substantial changes since then. On the 13th of May, 2020, the Aatmnirbhar Bharat package announced a modification in MSME classification criteria. This was done in order to be realistic with time, build an objective classification system, and make doing business easier. 


\subsection{Growth and Performance of the MSME Sector}

Through business innovations, Micro, Small, and Medium Enterprises (MSMEs) have made major contributions to the expansion of entrepreneurial endeavors. MSMEs are expanding their sphere of influence across the economy, generating a diversified range of products and services to fulfill the needs of both domestic and international markets. The contribution of the MSME sector to the country's Gross Value Added (GVA) and Gross Domestic Product (GDP) at current prices from 2014-15 to 2018-19 is as follows, according to statistics from the Central Statistics Office (CSO), M/o Statistics \& Programme Implementation:

:

Table 1

Share of Gross Value Added (GVA) of MSME in all India GDP

\begin{tabular}{|c|c|c|c|c|c|c|}
\hline \multicolumn{7}{|c|}{ Figures in Rs. Crores adjusted for FISIM at current prices } \\
\hline Year & Total MSME GVA & Growth $(\%)$ & Total GVA & $\begin{array}{c}\text { Share of MSME in } \\
\text { GVA }(\%)\end{array}$ & All India GDP & $\begin{array}{c}\text { Share of MSME in } \\
\text { All India GDP (in } \\
\% \text { ) }\end{array}$ \\
\hline $2014-15$ & 3658196 & - & 11504279 & 31.80 & 12467959 & 29.34 \\
\hline $2015-16$ & 4059660 & 10.97 & 12574499 & 32.28 & 13771874 & 29.48 \\
\hline $2016-17$ & 4502129 & 10.90 & 13965200 & 32.24 & 15391669 & 29.25 \\
\hline $2017-18$ & 5086493 & 12.98 & 15513122 & 32.79 & 17098304 & 29.75 \\
\hline $2018-19$ & 5741765 & 12.88 & 17139962 & 33.50 & 18971237 & 30.27 \\
\hline
\end{tabular}

Source: Central Statistics Office (CSO), Ministry of Statistics and Programme Implementation

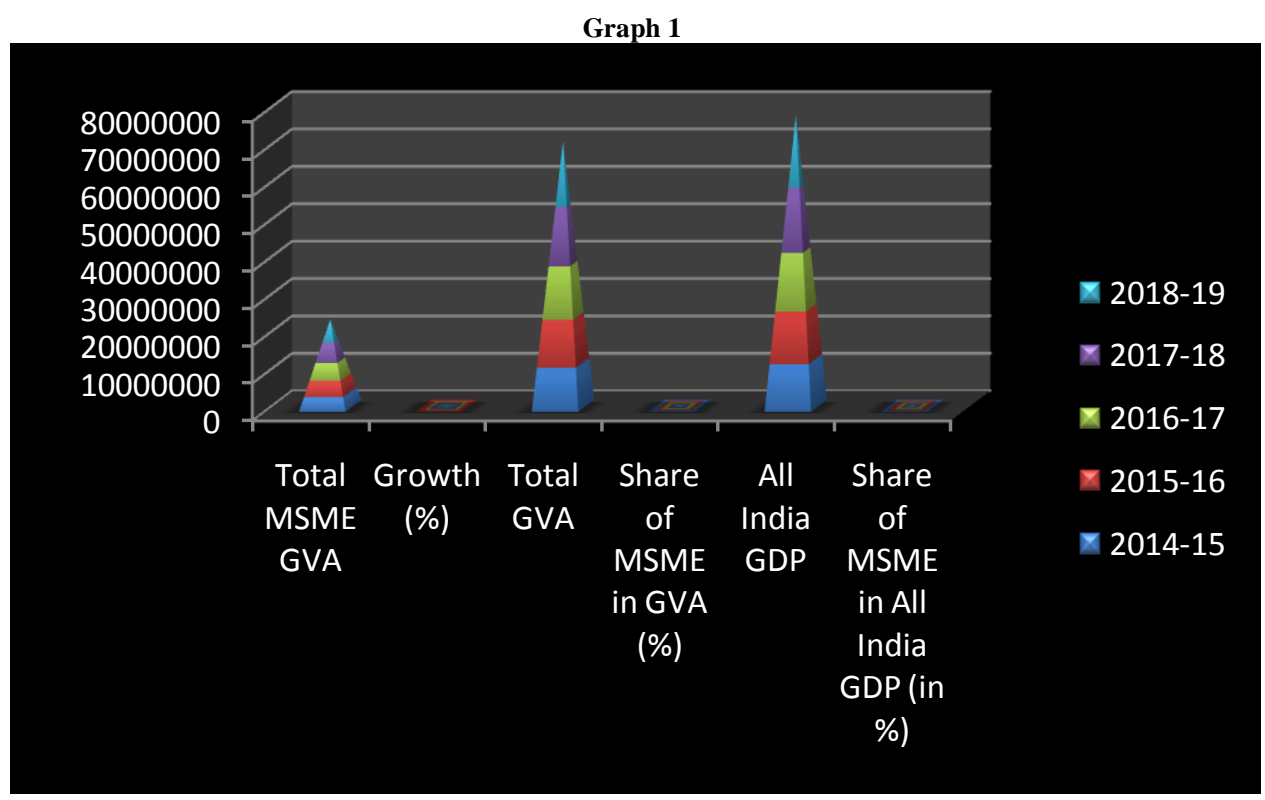

The Micro, Small, and Medium Enterprises (MSMEs) sector contributes significantly to the country's socioeconomic development. The sector has grown in prominence in India as a result of its contribution to the country's Gross Domestic Product (GDP) and exports. The sector has also made significant contributions to entrepreneurship growth, particularly in India's semi-urban and rural areas. There are roughly 6.3 crore MSMEs in India. According to data from the MSME Ministry, the Udyam Registration platform registered 5,767,734 MSMEs as of November 26, 2021, replacing the previous method of registering for an Udyog Aadhaar Memorandum (UAM). Micro-enterprises accounted for 5,441,220 (94.34 percent), small businesses for 293,555 (5.09 percent), and mid-sized businesses for 32,959. (0.57 percent ). Maharashtra has the most registrations (12.18 lakh) among the top five states for Udyam registrations as of November 26, 2021, followed by Tamil Nadu (6.23), Gujarat (4.86), Rajasthan (4.68), and Uttar Pradesh (4.68). (4.45). Since July 1, 2020, the Union MSME Ministry's new online MSME/Udyam Registration system has successfully registered over 5.7 million MSMEs through November 2021. Through national and international trade, the Indian MSMEs sector contributes roughly $29 \%$ to the GDP.

\subsection{Contribution of MSMEs to GDP}

According to data from the Central Statistics Office, Ministry of Statistics and PI, MSME Gross Value Added (GVA) in All India Gross Domestic Product for the years 2018-19 and 2019-20 was 30.5 percent and 30.0 percent, respectively, at current prices (2011-12). The micro, small, and mediumsized enterprise (MSME) sector is a vital part of the Indian economy. According to data from the Central Statistics Office, Ministry of Statistics and PI, MSME Gross Value Added (GVA) in All India Gross Domestic Product at current prices (2011-12) was 30.5 percent in 2018-19 and 30.0 percent in 2019-20, respectively. During the years 2018-19 and 2019-20, MSME manufacturing accounted for $36.9 \%$ and $36.9 \%$ of total manufacturing gross 
value production in India, respectively. Furthermore, according to data from the Directorate General of Commercial Intelligence and Statistics, the contribution of MSME-related exports to all-India exports in 2019-20 and 2020-21 was 49.8\% and 49.5 percent, respectively. According to the Ministry of Statistics and PI's 73rd Round of NSS Report on Unincorporated Non-Agricultural Enterprises (July 2015-June 2016), the estimated number of workers in the MSME sector was 11.10 crore. The estimated employment generated (number of people) in micro firms under the Prime Minister's Employment Generation Programme (PMEGP) for the years 2020-21 and 2021-22 (as of 01.07.2021) is 5.95 lakh and 1.19 lakh, respectively.

\subsection{Types of Industrial Finance}

Finance is an important component in manufacturing, distribution, and development. As a result, it is accurately defined as industry's "life-blood" and is a prerequisite for speeding up the process of industrial development. Entrepreneurs want three different sorts of funds: short-term, medium-term, and long-term. The graph below depicts the various types of industrial finance.

Figure

Types of industrial finance

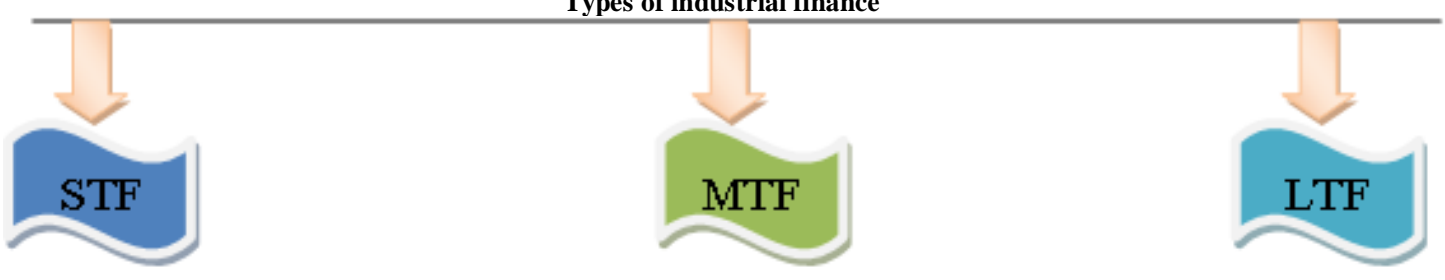

\section{- Short-term finance (STF)}

Short-term financing typically refers to money needed for a period of less than a year. Variable, seasonal, or transitory working capital requirements frequently necessitate short-term financing. Borrowing from banks is a critical source of short-term capital. Trade credit, instalment credit, and client advances are all key sources of short-term financing. For example, to purchase raw materials, pay labor wages, or meet any other day-to-day requirement.

\section{- Medium-term finance (MTF)}

The period of one year to five years may be regarded as a medium-term. Medium-term finance is usually required for permanent working capital, small expansions, replacements, modification, etc. Medium-term finance may be raised by:

1. Issues of shares;

2. Issue of debentures'

3. Borrowing from banks and other financial institutions; and

4. Ploughing back of profits (by existing concerns).

\section{- Long-term finance (LTF)}

Long-term is commonly defined as a period of more than 5 years. Long-term financing is necessary for the acquisition of fixed assets, the start-up of a new firm, significant expansion of an existing business, and modernization, among other thingsThe important sources of long-term finance are:

1. Issue of shares;

2. Issue of debentures;

3. Loans from financial institutions; and

4. Ploughing back of profits (for existing concerns).

\section{Schemes for Financing Micro, Small and Medium Enterprises}

In the post-World Trade Organization (WTO) era, it is evident that small industrial units must be cost competitive and produce high-quality items in order to stay in business. Small industrial units would benefit from incentives for obtaining ISO-9000 certification, as well as a Credit Linked Capital Subsidy Scheme (CLCSS), Technology Upgradation Scheme, and Credit Guarantee Fund Trust (TGSCGPT) for Small Industries, accord ing to the SSI ministry.

\section{Schemes implemented by M/o MSME \& its Organisations}

1. Prime Minister's Employment Generation Programme (PMEGP)

2. $2^{\text {nd }}$ Loan for up-gradation of the existing PMEGP/MUDRA units

3. Credit Guarantee Scheme for Micro \& Small Enterprises (CGTMSE)

4. Credit Linked Capital Subsidy Component (CLCS \& TU Scheme)

5. Procurement and Marketing Support (PMS) scheme

6. International Cooperation (IC) Scheme

7. Micro \& Small Enterprises Cluster Development Programme (MSE- CDP)

8. Scheme of Fund for Regeneration of Traditional Industries (SFURTI)

9. A Scheme for Promotion of Innovation, Rural Industries and Entrepreneurship (ASPIRE) 
10. ZED Certification Scheme

11. Lean Manufacturing Competitiveness for MSMEs

12. Design Clinic for Design Expertise to MSMEs

13. Digital MSME

14. Entrepreneurial and Managerial Development of SMEs through Incubators

15. Awareness on Intellectual Property Rights (IPR)

16. Entrepreneurship Skill Development Programme (ESDP) Scheme

17. National SC-ST Hub

18. Assistance to Training Institutions (ATI) Scheme

19. Coir Industry Technology Upgradation Scheme

20. Skill Upgradation and Mahila Coir Yojana

21. Interest Subsidy Eligibility Certificate (ISEC)

22. Work-Shed Scheme for Khadi Artisans

23. Rojgar Yukt Gaon

24. Mahatma Gandhi Institute for Rural Industrialization (MGIRI)

\subsection{New Schemes}

1. Pottery Activity under Gramodyog Vikas Yojana (GVY) Scheme

- To increase the production, technical knowhow of pottery artisans and to reduce cost of production

- To enhance the income of pottery artisans by providing skill development training and modern and automated equipment

- To provide skill-development training to SHGs of potteryartisans on focused products like garden pots, khullad, decorator products etc.

- To encourage the successful potter to set up his own unit under PMEGP scheme

- To develop necessary market linkages by tying up with exports and large buying houses.

- To innovate various new products and raw materials to make international scale pottery

2. Beekeeping Activity under "Gramodyog Vikas Yojana (GVY) Scheme

- To adopt scientific bee management practices

- To utilize available natural resources in beekeeping

- To create sustainable employments for the beekeepers / farmers

- To provide supplementary income for the beekeepers / farmers

- To create awareness about Honey and other Hive Products and benefits of beekeeping in cross pollination

3. Agarbatti Making Project under "Gramodyog Vikas Yojana(GVY) Scheme

- To revive Agarbatti industry in the country and increase indigenous production of Agarbatti to reduce imports

- To impart training to the artisans working in the Agarbatti sector and assist them with Agarbatti manufacturing machines, raw material for manufacturing Agarbatti. etc.

- To create sustainable employment for the traditional Artisans and increase their wages

- To develop backward and forward linkages and hand holding support to the artisans, SHGs etc.

4. Tool Rooms and Technical Institutions - A Component of Infrastructure Development \& Capacity Building scheme: Tool Room \& Technical Institutions are concentrated on an integrated Development of the relevant sector of industries to help MSME. Total 18 MSME Tool Rooms \& Technical institutions established PAN India serving in the relevant sector like General Engineering, foundry \& forging, electronics, fragrance, glass, sports good and footwear etc.

\section{Role of Credit Guarantee Fund Trust for Micro \& Small Enterprises (CGTMSE) in facilitating Institutional loans}

In August 2000, the Ministry of MSME and SIDBI collaborated to establish CGTMSE to facilitate access to finance for un-served / under-served borrower segments by making financial assistance available from lenders to first-generation entrepreneurs and underprivileged sections of society who lack collateral security and/or third-party guarantee for their ventures.

CGTMSE has approved over 34 lakh guarantees11 covering loans totaling over Rs. 1.75 lakh crore throughout the last 18 years of operations. Any collateral / third party guarantee free credit facility (both fund and non fund based) granted by qualified banks to new and existing Micro and Small Enterprises, including Service Enterprises, with a credit cap of Rs. 200 lakh (Rupees Two Hundred lakh only) is eligible to be covered. Select NBFCs and Small Finance Banks have recently become eligible for guarantee coverage.

The guarantee cover available under the scheme is 50 percent, 75 percent, 80 percent, and 85 percent of the credit facility's sanctioned amount. For micro firms with financing up to Rs. 5 lakh, the guarantee coverage is 85 percent. For loan between Rs. 10 lakh and Rs. 100 lakh per MSE borrower for retail trade activity, the guarantee cover is 50 percent of the sanctioned amount of the credit facility. The guarantee covers I all credit/loans in the North East Region (NER) for credit facilities up to Rs. 50 lakh; and (ii) all Micro and Small Enterprises operated and/or owned by women. In the event of a default, Trust pays up to $75 \%$ of the amount owed under the credit facility given by the lending institution for credit facilities up to Rs. 200 lakh. Over 
time, the Credit Guarantee Scheme has shown to be a successful tool for facilitating MSEs' access to traditional credit sources.

The Scheme aims to shift lenders' focus away from collateral-based lending and toward project liability. With the assurance of guarantee cover, CGTMSE has been able to inspire confidence and urge MLIs to increase loan flow to MSEs. Because the Scheme focuses solely on the MSE sector, which is the backbone of the Indian economy, the positive externalities in terms of GDP contribution and job creation are enormous.

CGTMSE has always been proactive and responsive in safeguarding the trust's long-term viability and serving the demands of the MSME sector. The rise in credit guarantee flow exhibited by CGTMSE in the graph below demonstrates the impact of upgrades to credit guarantee products with changing sector needs. MSMEs have reaped the benefits of this program on a regular basis. However, when we look at the guarantee fees levied under this program, we can see from the table below that the guarantee fees for potential and even existing MSEs are quite substantial.

Graph

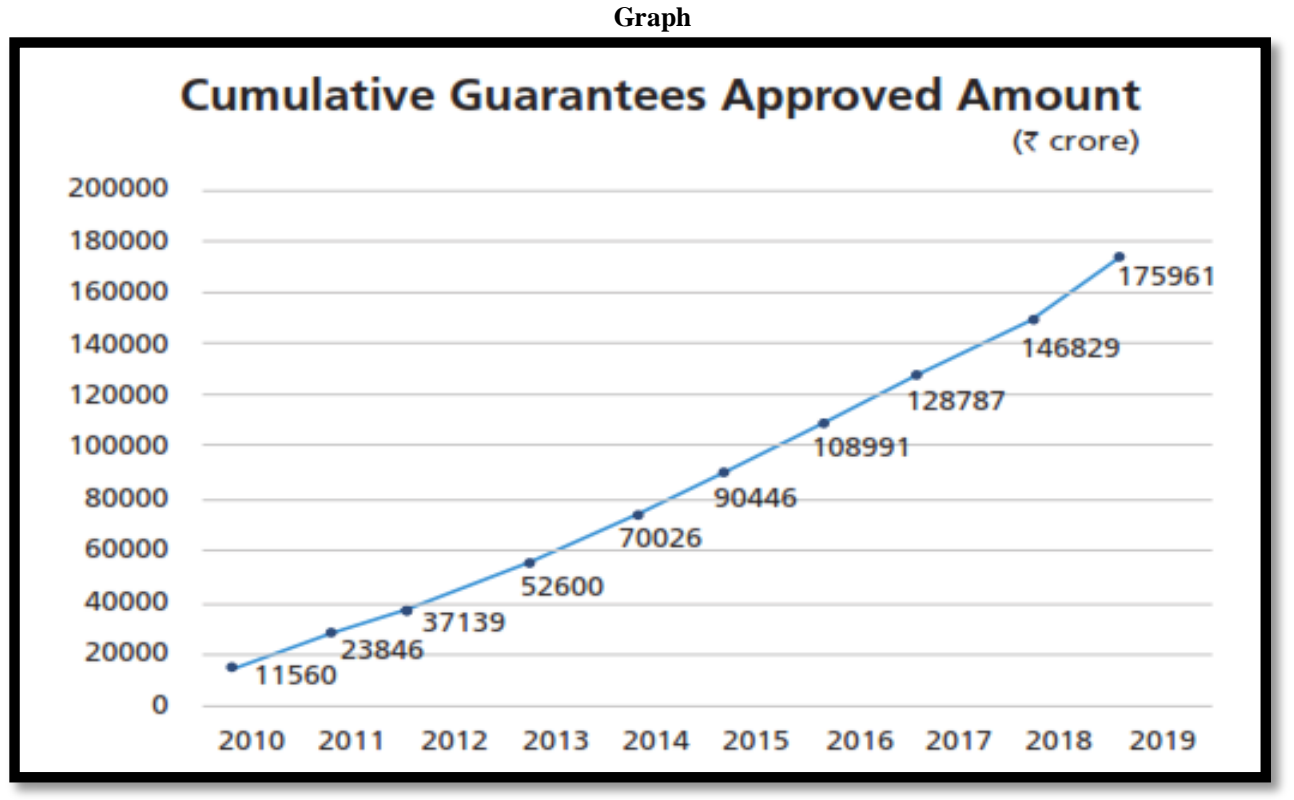

Source: Annual Progress Report 2018-19, CGTMSE, Mumbai

Micro, Small, and Medium Enterprises (MSMEs) make up a large part of the Indian economy and are one of the most powerful driv ers of economic growth, innovation, and employment. Access to capital is commonly cited as a major impediment to MSMEs' growth. Creating possibilities for MSMEs in emerging markets is a critical step toward economic development and poverty reduction. The MSME sector has come to exemplify the ability of the Indian entrepreneur to innovate and produce solutions despite the hurdles, with a continuous growth rate of over $10 \%$ in recent years. The importance and role of the MSME sector as the central driving force behind India's assertive vision to be a dominant global economic power cannot be overstated, as it generates more than 111 million jobs through 63.38 million enterprises 1 and contributes over 28 percent of the nation's GDP and more than 40 percent of the country's overall exports.

\section{Microfinance in India}

The Self Help Group movement is a ground-breaking project that connects group members to formal financial services in a sustainable and scalable manner, many of whom have never had a bank account before. The model's origins are indigenous. Shares are often economically homogeneous groupings formed through a self-selection process based on the members' affinity. SHGs have well-defined rules and bye-laws, meet on a regular basis, keep records, and practice financial and credit discipline. As a result, SHGs are self-managed institutions with a participatory and collaborative decision-making process.

The National Bank for Agriculture and Rural Development (NABARD) began a pilot program in 1991-92 to link Self Help Groups (SHGs) to banks, and since then, NABARD has propagated, promoted, and funded the SHG-Bank Linkage Program (SHG-BLP).

\subsection{Progress of SHG Bank Linkage Programme}

With a reach of 13.87 crore families, the SHG-BLP program has proven to be a global success in terms of microfinance, giving social, economic, and financial empowerment to the rural poor, particularly women. The development of SHGs under the SHG-BLP in terms of savings and credit linkage is listed in Table and illustrated in Figure, which presents an account of savings, credit disbursement, and credit outstanding for all SHGs, including those under NRLM and NULM. 


\section{Graph \\ Progress of SHG BLP (2018-19 to 2020-21)}

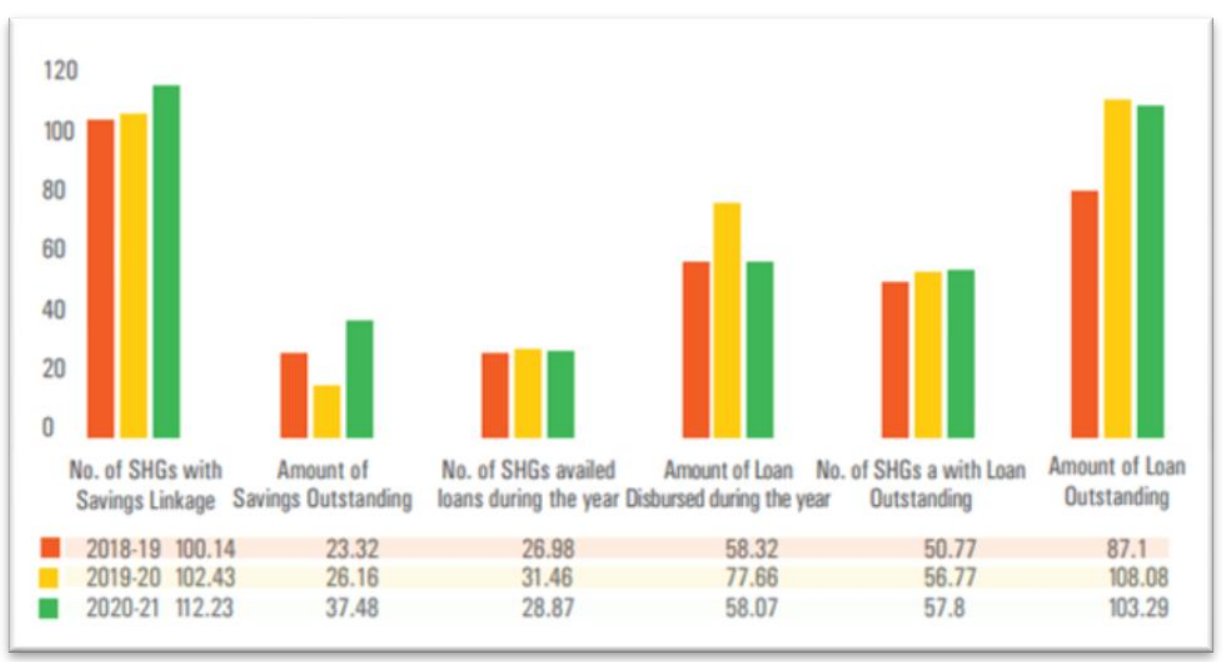

Source: Status of Microfinance in India 2020-21(NABARD)

\subsection{Progress of Savings Linkage of SHGs with Banks (2018-19 to 2020-21)}

As SHGs' savings rise, they become more eligible for bank/FI loans, increasing their company investment potential. Table and Figure show the performance of SHG savings linkage in terms of absolute numbers and percentage share per region. Banks reported an addition of 9.8 lakh savingslinked SHGs across India in 2020-21, a growth of 9.5 percent compared to 2.3 percent in 2019-20. Comparative data by region demonstrates that during 2020-21, all regions experienced positive growth in the number of SHG savings linked to banks. The Central region experienced the fastest growth of 19 percent, while the Western region experienced the slowest growth of 5 percent. Uttarakhand, Nagaland, Chandigarh, New Delhi, Karnataka, Daman \& Diu, and Uttarakhand, Nagaland, Nagaland, Nagaland, Nagaland, Nagaland, Nagaland, Nagaland, Nagaland, Nagaland, Nagaland, Nagaland, Nagaland, Nagaland, Nagaland, Nagaland, Chhattisgarh, Madhya Pradesh, Andaman \& Nicobar, Bihar, Odisha, Arunachal Pradesh, Assam, Manipur, Meghalaya, Mizoram, Tripura, Haryana, Jammu \& Kashmir, Punjab, Andhra Pradesh, Lakshadweep, Puducherry, Telangana, and Gujarat were among the 19 states/UTs that had growth rates higher than the national average. The drop in SHG savings accounts is mostly due to data sanitization, the closure of dormant accounts, and reporting errors, among other factors. The Northern Region had the biggest savings growth of 193 percent, followed by the Western Region ( 85 percent), North Eastern Region (73 percent), Southern Region (45 percent), Central Region (24 percent), and Eastern Region (17 percent).

Table

Region-wise progress of Savings Linked SHGs with Banks (2018-19 to 2020-21)

\begin{tabular}{|c|c|c|c|c|c|c|c|}
\hline \multirow{2}{*}{$\begin{array}{l}\text { Sr. } \\
\text { No. }\end{array}$} & \multirow[t]{2}{*}{ Regions } & \multicolumn{2}{|c|}{$2018-19$} & \multicolumn{2}{|c|}{$2019-20$} & \multicolumn{2}{|c|}{$2020-21$} \\
\hline & & No. of SHGs & Savings-Amount & No. of SHGs & $\begin{array}{l}\text { Savings } \\
\text { Amount }\end{array}$ & No. of SHGs & Savings Amount \\
\hline 1 & Northern Region & $5,48,624$ & 62,453 & $5,77,122$ & 59,550 & $6,09,808$ & $1,74,345$ \\
\hline 2 & $\begin{array}{l}\text { North } \quad \text { Eastern } \\
\text { Region }\end{array}$ & $5,23,469$ & 40,407 & $5,56,899$ & 48,141 & $6,33,714$ & 83,126 \\
\hline 3 & Eastern Region & $26,54,358$ & $6,01,155$ & $28,11,130$ & $6,64,333$ & $31,22,424$ & $7,74,912$ \\
\hline 4 & Central Region & $10,62,759$ & $1,33,230$ & $11,35,083$ & $1,71,217$ & $13,45,575$ & $2,11,870$ \\
\hline 5 & Western Region & $13,88,615$ & $2,05,275$ & $14,73,853$ & $2,01,880$ & $15,50,176$ & $3,74,023$ \\
\hline 6 & Southern Region & $38,36,418$ & $12,89,928$ & $36,89,236$ & $14,70,085$ & $39,61,703$ & $21,29,485$ \\
\hline & Total & $1,00,14,243$ & $23,32,448$ & $1,02,43,323$ & $26,15,205$ & $1,12,23,400$ & $37,47,761$ \\
\hline
\end{tabular}

Source: Status of Microfinance in India 2020-21 (NABRD) 
Graph

Regional Distribution of Savings linked SHGs (\% share)

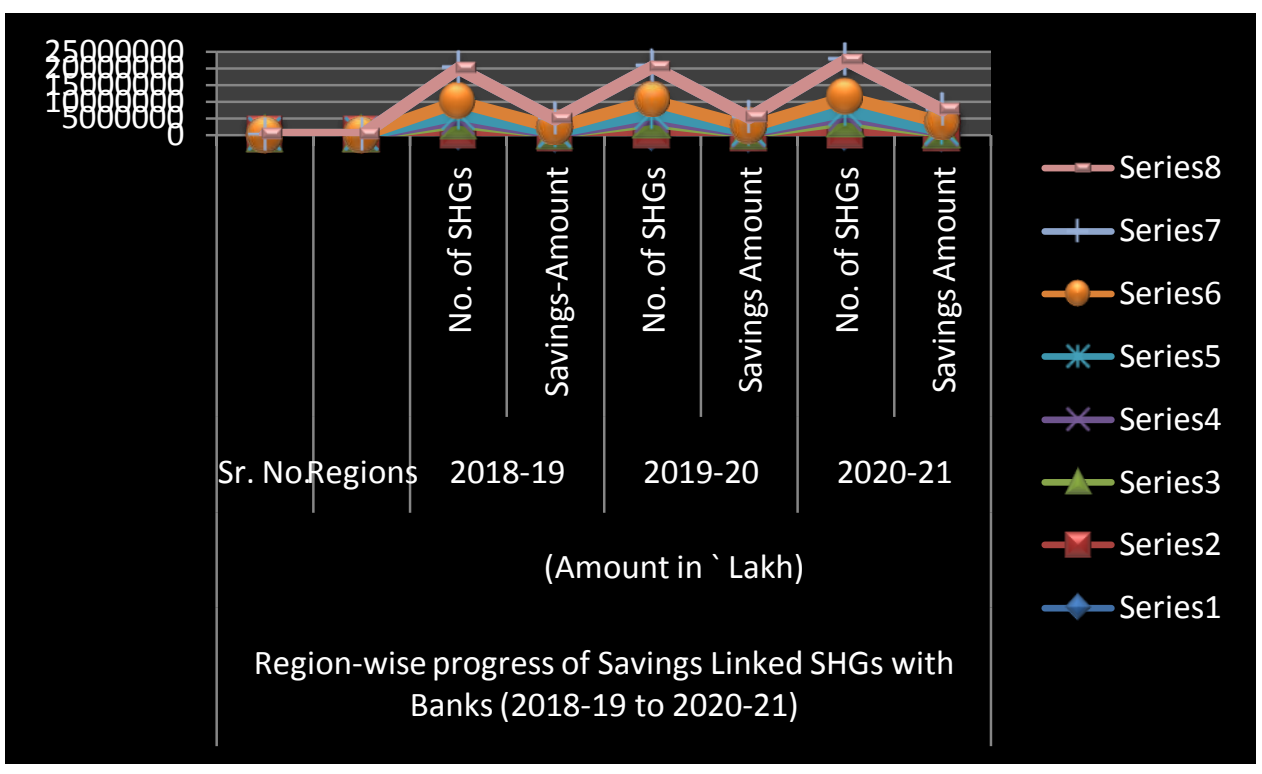

As shown in Figure, the Southern Region has the biggest percentage share of savings connected SHGs at 35.3 percent, however this represents a 0.7 percent decrease from 2019-20. The Eastern Region maintains its second-highest share (27.8\%), with a very slight rise over the previous year (27.4 percent ). With a share of 13.8 percent in 2020-21, the Western region is in third place, but it is down slightly from the previous year (14.4 percent ).

\subsection{Review of the operations of MFIs}

In India, the microfinance business is varied, with a variety of players providing low-income people with financial services such as lending, insurance, and pensions. NGOMFIs that operate as societies, trusts, section 8 companies, co-operatives (including banks), public and private sector banks, NBFCs, NBFCMFIs, and SFBs are among them. Because their legal and operating environments differ, regulation has become a hot topic in the microfinance business over the years. With banks, NBFC-MFIs, and now SFBs all involved in microfinance, the RBI has stepped in with a variety of policy directions aimed at bringing uniformity and standards to the operating structure and retail service operations in order to improve transparency and protect customers. MFIs have been focusing on technology and digitization of procedures in recent years, which has helped to streamline operations, decrease costs, and shorten customer service turnaround times.

Since 2011, RBI's microfinance-related Master Circulars have outlined the do's and don'ts for MFIs and introduced stronger standards of compliance. The definition of qualifying assets has aided in the standardization of targeted outreach in terms of income qualification, loan size, loan exclusions, and interest rate regulation, among other things. The loan provisioning guidelines are aimed at preserving asset quality and, as a result, supporting conservative behavior. Microfinance helps underserved people who have limited financial resources, a lack of education, and are unfamiliar with financial and banking activities. As a result, the Fair Practices Code requires all RBI-regulated firms to follow a set of customer/consumer protection guidelines in order to ensure complete fairness and transparency in terms of customer onboarding, engagement, and grievance redress. Because the Covid-19 epidemic impacted all stakeholders, RBI issued policy instruction in March 2020 to grant a three-month moratorium to microfinance clients, and because the pandemic impacted client repayments to MFIs, RBI also released loan loss provisioning guidelines.

MFIN and Sa-Dhan have been approved by the RBI as self-regulatory organizations for the microfinance industry. The role of self-regulatory organizations (SROs) has enabled a number of new initiatives aimed at establishing common operating rules, creating a level playing field for all types of operators, ensuring transparency in lending practices, and resolving and protecting customer grievances. All of the member players have agreed to the Code of Conduct and the Code for Responsible Lending, which has systematized the effort for self-regulation by following a common set of guidelines and principles. Hotlines have been set up across India to gather customer input, and the SROs send feedback to the various organizations for addressing problems and ensuring continual improvement in order to meet the responsible lending standards through a systematically stated process. SROs are also important in delivering industry updates to the RBI and other major government organizations, contributing to policy initiatives. Another regulatory measure that has enabled microfinance players to work on the principles of responsible lending and make informed lending decisions is the submission of weekly portfolio information to CICs. The SROs keep a close eye on this process and use the data from across India to generate wellanalyzed and useful information for the industry. A credit bureau report can also be used to educate clients and help them maintain a good credit profile.

\subsection{Progress of MFI operations during 2020-21}

NBFCMFIs, Banks, SFBs, NBFCs, and Non-profit MFIs are the five types of microfinance players. Except for non-profit MFIs, all of these are regulated by the RBI. The majority of non-profit MFIs are registered as Societies or Trusts, and are governed by the relevant Acts. As shown in Table, there were 209 lenders in 2020-21, including 87 NBFC-MFIs, 58 NBFCs, 39 Non-profit MFIs, 17 Banks, and 8 SFBs, compared to 141 lenders in 2019-20. The total industry loan outstanding as of March 31, 2021 is anticipated to be Rs. 247839 crores, with 1028 lakh active borrowers, representing 
a 17 percent and 12 percent increase over the previous financial year, respectively. SFBs and NBFCs experienced a negative rise in active loans and outstanding portfolio in 2020-21.

Table 7

Type of Lenders and Loans Outstanding in Microfinance Sector

\begin{tabular}{|c|c|c|c|c|c|c|}
\hline \multirow[t]{2}{*}{ Type of Lender } & \multicolumn{2}{|l|}{ 2019-20 } & \multicolumn{2}{|c|}{$2020-21$} & \multicolumn{2}{|c|}{ Growth $(\%)$} \\
\hline & No. of Active Loans & O/S Balances & No. of Active Loans & O/S Balances & No. of Active Loans & O/S Balances \\
\hline NBFC-MFI & 356 & 72,110 & 359 & 79,115 & $0.9 \%$ & $9.7 \%$ \\
\hline Banks & 303 & 81,001 & 416 & $1,10,122$ & $37.1 \%$ & $36.0 \%$ \\
\hline SFB & 168 & 38,986 & 163 & 37,724 & $-3.0 \%$ & $-3.2 \%$ \\
\hline NBFC & 84 & 18,073 & 78 & 18,765 & $-6.7 \%$ & $3.8 \%$ \\
\hline Non-profit MFI & 8 & 1,679 & 11 & 2,113 & $42.8 \%$ & $25.8 \%$ \\
\hline Total & 919 & $2,11,849$ & 1,028 & $2,47,839$ & $11.8 \%$ & $17.0 \%$ \\
\hline
\end{tabular}

Source: Status of Microfinance in India 2020-21 (NABRD)

Graph

Type of Lenders and Loans Outstanding in Microfinance sector

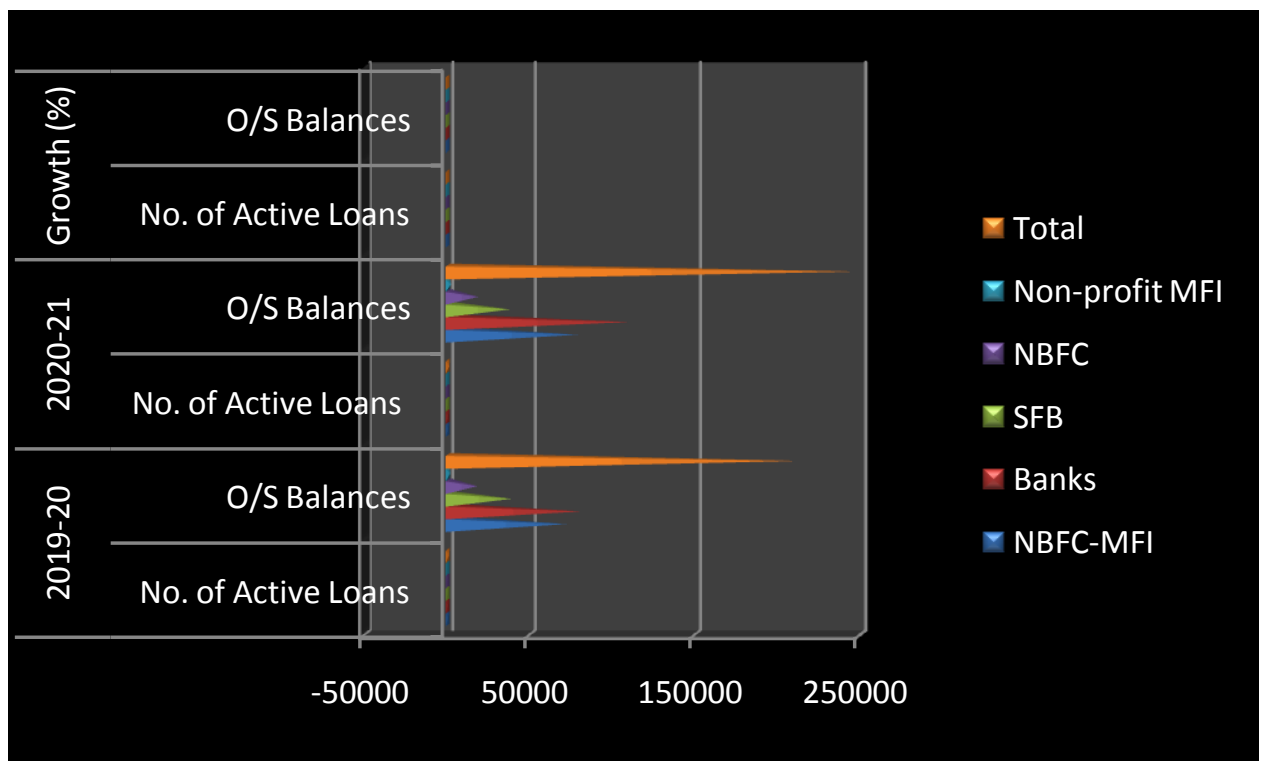

\section{Conclusion}

Credit Guarantee has proven to be a time-tested strategy for driving credit flow to the MSE sector around the world. To a considerable extent, increased credit guarantee support would be a factor in bridging the credit gap. The uptick in credit guarantee flow shown by CGTMSE in FY 2019 demonstrates the impact of enhancements to credit guarantee products with shifting sector needs. The Trust will continue to strengthen its role in increasing credit flow to the MSE sector, and so play an important part in the Indian economy's development. MSMEs have evolved into powerhouse s of the modern economy. MSMEs play an important role in all developed and emerging economies' industrial, economic, technical, and regional growth. With the emergence of new financial products, the model of funding micro, small, and medium firms is steadily shifting in favor of specialized, target-specific financial services. SFCs and SIDCs, as well as public sector banks, are planning to offer a diverse variety of services to various target groups, including venture capital, leasing, equipment finance, export finance, and factoring services. Finance, aptly described as "industry's life blood," is required for the mobilization of real resources to organize production and marketing. The Bank of India's Small Industrial Development Bank (SIDBI) is the country's primary financial institution for the MSME sector. Over the last five decades, the Micro, Small, and Medium Enterprises (MSME) sector has emerged as a highly vibrant and dynamic sector of the Indian economy. It makes a substantial contribution to the country's economic and social growth by encouraging entrepreneurship and creating enormous employment prospects at a low capital cost, second only to agriculture. MSMEs serve as ancillary units to large companies, and this sector contributes considerably to the country's inclusive industrial development.

\section{References}

1. Abraham Facundo and Schmukler Sergio L., Addressing the SME finance problem, Research and Policy Brief from the World Bank Malaysia Hub, No.9, and October, 2017.

2. Agrawal, A.N., and Gupta, K.K., (2001), Indian Economy, New Age International (p) Limited, New Delhi.

3. Ambrose, J. 2012. Venture Capital (VC): The All Important MSMEs Financing Strategy under Neglect in Kenya. International Journal of Business and Social Science. 3(21). pp. 234-240.

4. Annual Progress Report, Ministry of Micro, Small \& Medium Enterprises, 2017-18. 
5. Annual Report, CGTMSE, Mumbai, 2018-19.

6. Asian Development Bank. 2014. ADB-OECD Study on Enhancing Financial Accessibility for MSMEs: Lessons from Recent Crises. Manila.

7. Atma Nirbhar Bharat Package Announced by Hon'ble Minister of Finance, GoI, 13th May, 2020.

8. Banerjee, A. A. 2006. Capital Market Access to SMEs in India. Paper presented at the 10th Indian Institute of Capital Markets (IICM) Conference, 18-19 December, Mumbai, India.

9. Bebczuk, R. N. 2004. What Determines the Access to Credit by SMEs in Argentina? (Documento de Trabajo Nro. 48 [Working Paper No. 48 ]). Buenos Aires, Argentina: Universidad Nacional de la Plata.

10. Biswas, A. 2014. Financing Constraints for MSME Sector. International Journal of Interdisciplinary and Multidisciplinary Studies. 1(5). pp. 6068.

11. Centre for Industrial and Economic Research (CIER), New Delhi, India, available at :www.indiastat.com,

12. Chakrabarty, K. C. (2010), "Inclusive Growth - Role of Financial Sector" speech at the National Finance conclave.

13. Chawla, A.S (1987), Nationalization and Growth of Indian Banking. Deep and Deep Publications, New Delhi, p.216.

14. E.Gordon, and K.Natarajan (2012) Entrepreneurship Development, Mumbai: Himalaya publishing House.

15. Entrepreneurial Development, S. Chand and Company Limited, S.S. Khanka

16. Entrepreneurship - New venture Creation, Holt, and PHI.

17. Entrepreneurship Development \& Small Business Enterprises - Second Edition, Poornima M. Charantimath , Pearson

18. Entrepreneurship- Successfully Launching New Ventures, Barringer, Ireland, Pearson.

\section{AUTHORS PROFILE}

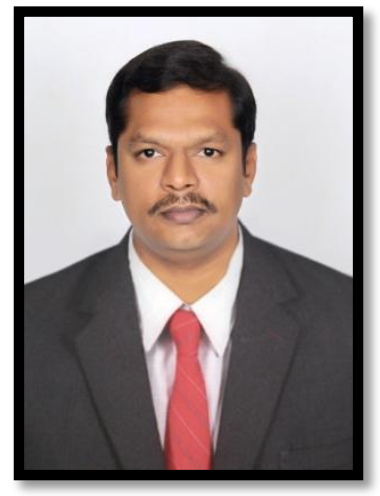

Currently, Dr. Nalla Bala Kalyan is working as an Associate Professor in the Department of Management Studies at Sri Venkateswara College of Engineering, Tirupati, Andhra Pradesh, India. He holds a Doctorate in Finance from Sri Venkateswara University, Tirupati in the year 2014. He has 12 years of experience in research and teaching. Right now he is serving as a Ph.D. Supervisor of Jawaharlal Nehru Technological University, Anantapur. $\mathrm{He}$ is the author of more than 70 research papers published in various national \& international journals with high Impact fact or and citations, Top 10\% global authors of SSRN-Elsevier. He has attended more than 25 National and International conferences/seminars and presented papers that appeared in the proceedings (Book Chapters) published with ISBN and he has Authored \& Edited 15 books. He has posted more than 15 guest articles in Magazines and Blogs. He is the Editorial/Advisory/Reviewer Board Member of more than 45 National \& International Journals. He has organized many programs (DST-NIMAT Projects, Govt. of India) for imparting entrepreneurship skills among students and faculty. He has taken an interest in 20 Faculty Development Programs. He received several outstanding awards for his academic achievements.

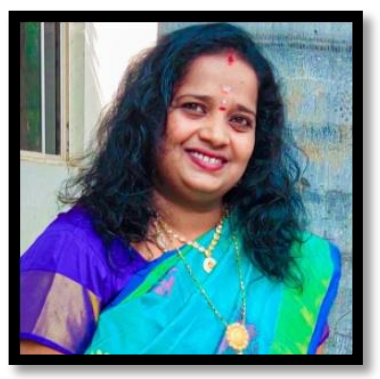

Mrs. ToopalliSirisha Working as an Assistant Professor in the Department of Management Studies at Sri Venkateswara College of Engineering, Tirupati. She has a experience of 13 years in research and teaching. She guided 100 PG (Management) Projects. She authored more than 30 research papers, published in various national \& international journals with high Impact Factor and citations, Top 10\% global authors of SSRN-Elsevier. She has attended more than 15 National and International conferences/seminars/Workshops and presented papers which appeared in the proceedings published with ISBN. She has Authored 3 books. She has Received "Young Researcher Award 2019" from Green ThinkerZ, India. She is a professional life time member of IARA, IAASSE, IFERP, IMRTC, and Green ThinkerZ. 